\title{
Note on Sources ANd List of AbBreviations
}

I have, wherever possible, followed the most accessible English-language translations and editions of Nietzsche's major works-those by Walter Kaufmann and R. J. Hollingdale. All quotations from Nietzsche's writings are given in the text and identified by abbreviations of their English titles. Arabic numbers not identified as page numbers indicate the paragraphs or sections in which the passages appear. Where appropriate, Roman numerals are used to indicate the parts of the works in which they are to be found.

Citations from Nietzsche's other works are based on the texts as they appear in the Colli-Montinari Kritische Studienausgabe (KSA), and their Sämtliche Briefe: Kritische Studienausgabe (KGB). All translations are mine, unless otherwise noted. The transliteration of Hebrew titles of journals is according to "Newspapers and Periodicals, Hebrew," in Encyclopedia Judaica.

A The Antichrist. In The Portable Nietzsche. Translated and edited by Walter Kaufmann. New York, 1954.

BGE Beyond Good and Evil. Translated by Walter Kaufmann. New York, 1966.

BT The Birth of Tragedy. Translated by Walter Kaufmann. New York, 1967 .

CW The Case of Wagner. In The Birth of Tragedy.

$D \quad$ Daybreak. Translated by R. J. Hollingdale. Cambridge, 1982.

E Ecce Homo. Translated by Walter Kaufmann. New York, 1967 .

GM On the Genealogy of Morals. Translated and edited by Walter Kaufmann. New York, 1967.

GS The Gay Science. Translated by Walter Kaufmann. New York, 1974.

HH Human, All Too Human. Translated by R. J. Hollingdale. Cambridge, 1986.

HL "On the Uses and Disadvantages of History for Life." In Untimely Meditations.

KGB Sämtliche Briefe: Kritische Studienausgabe. Edited by Giorgio Colli and Mazzino Montinari. 8 vols. Berlin, 1975-1984.

KSA Kritische Studienausgabe. Edited by Giorgio Colli and Mazzino Montinari. 15 vols. Berlin, 1967-1977. 
NCW "Nietzsche contra Wagner." In The Portable Nietzsche.

NFP Neue Freie Presse.

SE "Schopenhauer as Educator." The third of the Untimely Meditations.

TI "Twilight of the Idols." In The Portable Nietzsche.

UM Untimely Meditations. Translated by R. J. Hollingdale. Cambridge, 1983 .

WP The Will to Power. Translated by Walter Kaufmann and R. J. Hollingdale. New York, 1967.

Z "Thus Spoke Zarathustra." In The Portable Nietzsche.

In addition, the following editions of works by Nietzsche are occasionally cited.

Basic Writings of Nietzsche. Translated by Walter Kaufmann. New York, 1968.

Kritische Gesamtausgabe der Werke Nietzsches. Edited by Giorgio Colli and Mazzino Montinari. 33 vols. Berlin, 1967ff.

Philosophy in the Tragic Age of the Greeks. Translated by Marianne Cowan. Chicago, 1962. 


\section{Nietzache AND Zion}


